\title{
Immunocytochemical study of the cellular immune response in meningiomas
}

\author{
M L ROSSI, F CRUZ SANCHEZ, J T HUGHES, M M ESIRI, H B COAKHAM* \\ From the Department of Neuropathology, Radcliffe Infirmary, Oxford, and the *Imperial Cancer Research \\ Brain Tumour Group, Frenchay Hospital, Bristol
}

SUMMARY Twenty four meningiomas (17 benign and seven "atypical" were reacted with a panel of monoclonal antibodies to macrophages, lymphocytes, and HLA DR antigens. All the tumours contained macrophages but these cells were more numerous in the atypical meningiomas. Lymphocytes, almost exclusively of the CD8 subtype, were also present in $70 \%$ of benign meningiomas and in all atypical meningiomas and were more abundant in the latter. B lymphocytes were present in minimal numbers in three atypical meningiomas and in one benign meningioma. CD4 positive $\mathrm{T}$ lymphocytes were present in small numbers in one benign meningioma and in moderate numbers in one atypical meningioma. HLA DR antigen expression on tumour cells was present in about $60 \%$ of both tumour groups.

The numbers of macrophages and T and CD8 lymphocytes in meningiomas seem to be related to atypical histological features, and the presence of these cells raises questions about host immune response and the relation of this to prognosis.

Mononuclear cells infiltrating tumours in man have been noted for at least a century ${ }^{1}$ but only lately has attention also been focused on tumours of the central nervous system. ${ }^{2-11}$ Very few reports dealing specifically with these cells in meningiomas have been published.

Some patients with meningiomas have a depressed systemic cellular immune response ${ }^{1213}$; others possess mononuclear white cells which are cytotoxic for their tumours. ${ }^{14-16}$ In one malignant meningioma studied in situ with antibodies to $T$ cell subsets ${ }^{10}$ and in a few benign meningiomas mononuclear inflammatory cells have been shown. 117

The present study examines the nature and extent of the mononuclear cell infiltrate in benign meningiomas and atypical meningiomas ${ }^{18}$ and gives information on the cellular immunity of these tumours.

\section{Material and methods}

Snap frozen tissue from 24 consecutive surgically excised meningiomas was available for study. Meningioma was diagnosed and categorised into benign or "atypical"18 on the basis of paraffin embedded sections stained wit', haematoxylin and eosin.

Accepted for publication 30 September 1987
The frozen tissue from the tumours was stored at $-70^{\circ} \mathrm{C}$ until used and $7 \mu \mathrm{m}$ cryostat sections were cut and reacted with a panel of antibodies against lymphocyte subsets, macrophages and HLA DR antigens (table 1).

Seven of the meningiomas were "atypical"--that is, they presented a high mitotic rate and at least one of the following histological findings: high cellularity, atypical mitosis, necrosis, and poor differentiation. ${ }^{18}$ Clear evidence of invasion of brain in the surgical specimen or clinical evidence of metastasis to extracranial organs were not present but two of the tumours were recurrences eight and 12 years after the first operation when they had shown atypical cytological features.

Of the 17 histologically benign meningiomas, 12 were of the transitional type, three of the fibroblastic type, one was meningotheliomatous and one haemangiopericytic. Frozen tissue blocks from the tumours were selected and the sections cut measured about 1 square $\mathrm{cm}$. Monoclonal antibody reactions were carried out using the indirect two stage immunoperoxidase technique. ${ }^{19}$ The sections studied did not show gross necrosis of the tumours. The approximate number and distribution of positive cells in the tumours were examined looking both at areas of tumour parenchyma (away from blood vessels) and 
Table 1 Antibodies used

\begin{tabular}{llll}
\hline Monoclonal antibody (dilution) & Isotype & Specificity & Source/reference \\
\hline RFD7 (1:1) & IgG1 & Macrophages & G Janossy, Royal Free Hospital \\
Y182A (1:1) & IgG3 & Macrophages & K Gatter, Oxford \\
RFDR1 (1:1) & IgM & HLA DR & G Janossy, Royal Free Hospital \\
VICY1 (1:100) & IgG1 & B lymphocytes & W Knapp, Vienna \\
RFBCT (1:1) & Cocktail & & G Janossy, Royal Free Hospital \\
& IgM (CD20) & T lymphocytes & G Janossy, Royal Free Hospital \\
IgG (CD20) & RFBT & & \\
RFTC (1:1) & Cocktail & & \\
& IgG (CD2) & & Dako \\
I8 (1:10) & IgG (CD3) & T (CD7) & Dako \\
T4 (1:10) & IgG (CD8Y) & Thelper/inducer & \\
\hline
\end{tabular}

perivascular spaces. Macrophages in the latter compartment were subdivided into perivascular and "pericytal" (defined as cells distinctly seen wrapped around blood vessels in a pericytal pattern). The density of positive cells in the various areas was assessed using a scale from 1 to 4 where 1 indicated occasional positive cells in a high power field $(\times 400) ; 2$ up to 20 cells; 3 from 20 to 40 cells; and 4 more than 40 cells.

\section{Results}

The results obtained with the antibodies RFD7, Y182A, RFTCT and T8 are given in table 2 which summarises results for atypical meningiomas and benign meningiomas separately.

Table 2 Meningiomas (benign and "atypical")
In benign meningiomas the antibody RFD? showed reactive cells (macrophages) in $76 \%$ of cases and Y182A in $93 \%$ within tumour parenchyma. More reactive cells (macrophages) were detected with Y182A (average cellularity 1.8 ) than RFD7 (average cellularity 1.4). Reactive cells (macrophages) were seen scattered throughout the tumours (fig 1) as well as in groups. In the same areas these cells formed perivascular collections, but in other areas they were intimately mixed with tumour cells including those forming whorls in meningiomas of the transitional type.

In atypical meningiomas macrophages were present in all cases with both antibodies, and the average cellularity was much higher than in benign meningiomas (3 with RFD7 and 3.7 with Y182A). Within

\begin{tabular}{|c|c|c|c|c|c|c|c|c|}
\hline \multirow[b]{2}{*}{ No of cases } & \multirow[b]{2}{*}{ Site } & \multicolumn{5}{|c|}{ Semiquantitative rating } & \multirow[b]{2}{*}{ Mean rate } & \multirow{2}{*}{$\begin{array}{l}\text { Percentage of } \\
\text { positive cases }\end{array}$} \\
\hline & & 0 & 1 & 2 & 3 & 4 & & \\
\hline \multicolumn{9}{|l|}{ RFD7 } \\
\hline 17 & Cellularity in tumour & 4 & 4 & 6 & 3 & & 1.4 & 76 \\
\hline 7 & proper & & & 2 & 3 & 2 & 3 & 100 \\
\hline 15 & Perivascular cellularity & 5 & 6 & 4 & & & 0.9 & 66 \\
\hline 7 & & & & 2 & 5 & & $2 \cdot 7$ & 100 \\
\hline 13 & "Pericytal" cellularity & 9 & 1 & 3 & & & $0 \cdot 5$ & 30 \\
\hline \multirow{2}{*}{\multicolumn{9}{|c|}{$Y 182 A$}} \\
\hline & & & & & & & & \\
\hline $\begin{array}{r}16 \\
7\end{array}$ & Cellularity in tumour & 1 & 1 & 11 & 2 & & $1 \cdot 8$ & 93 \\
\hline $\begin{array}{r}7 \\
13\end{array}$ & $\begin{array}{l}\text { proper } \\
\text { Perivascular cellularity }\end{array}$ & 2 & 6 & 3 & 2 & 5 & $\begin{array}{l}3.7 \\
1 \cdot 3\end{array}$ & $\begin{array}{r}100 \\
84\end{array}$ \\
\hline 7 & & & & 2 & $\begin{array}{l}2 \\
5\end{array}$ & & $\begin{array}{l}1 \cdot 3 \\
2 \cdot 7\end{array}$ & 100 \\
\hline 13 & "Pericytal" cellularity & 2 & 7 & 3 & 1 & & $1 \cdot 2$ & 84 \\
\hline 7 & & & 1 & 6 & & & $1 \cdot 8$ & 100 \\
\hline \multicolumn{9}{|l|}{ RFTCT } \\
\hline 17 & Cellularity in tumour & 1 & 11 & 5 & & & $1 \cdot 2$ & 94 \\
\hline $\begin{array}{r}7 \\
17\end{array}$ & $\begin{array}{l}\text { proper } \\
\text { Periollularity }\end{array}$ & 2 & 1 & 5 & 1 & & 2 & 100 \\
\hline 7 & Perivascular cellularity & 2 & 1 & 4 & 1 & 2 & $2 \cdot 3$ & $\begin{array}{r}88 \\
100\end{array}$ \\
\hline \multicolumn{9}{|l|}{$T 8$} \\
\hline $\begin{array}{r}17 \\
7\end{array}$ & Cellularity in tumour & 5 & 6 & 6 & & & 1 & 70 \\
\hline $\begin{array}{r}7 \\
17\end{array}$ & proper & 6 & 2 & 3 & 2 & & 2 & 100 \\
\hline 7 & Perivascular cellularity & 0 & $\begin{array}{l}7 \\
2\end{array}$ & $\begin{array}{l}3 \\
4\end{array}$ & $\begin{array}{l}1 \\
1\end{array}$ & & $\begin{array}{l}0.9 \\
1.8\end{array}$ & $\begin{array}{r}64 \\
100\end{array}$ \\
\hline
\end{tabular}




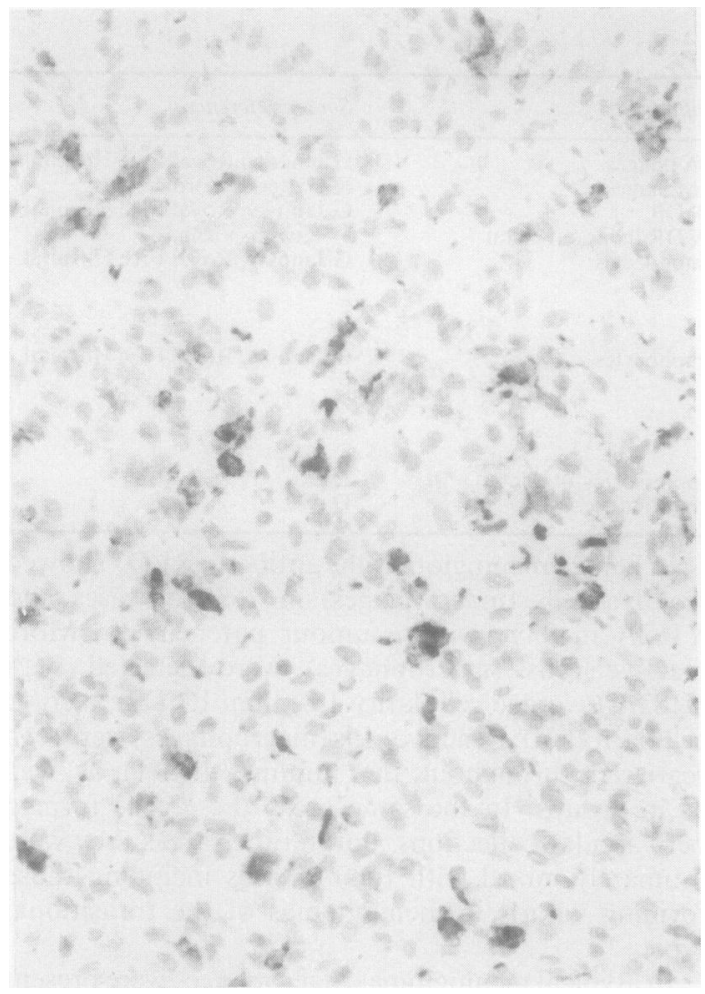

Fig 1 Benign meningioma: scattered macrophages in parenchyma (RFD7).

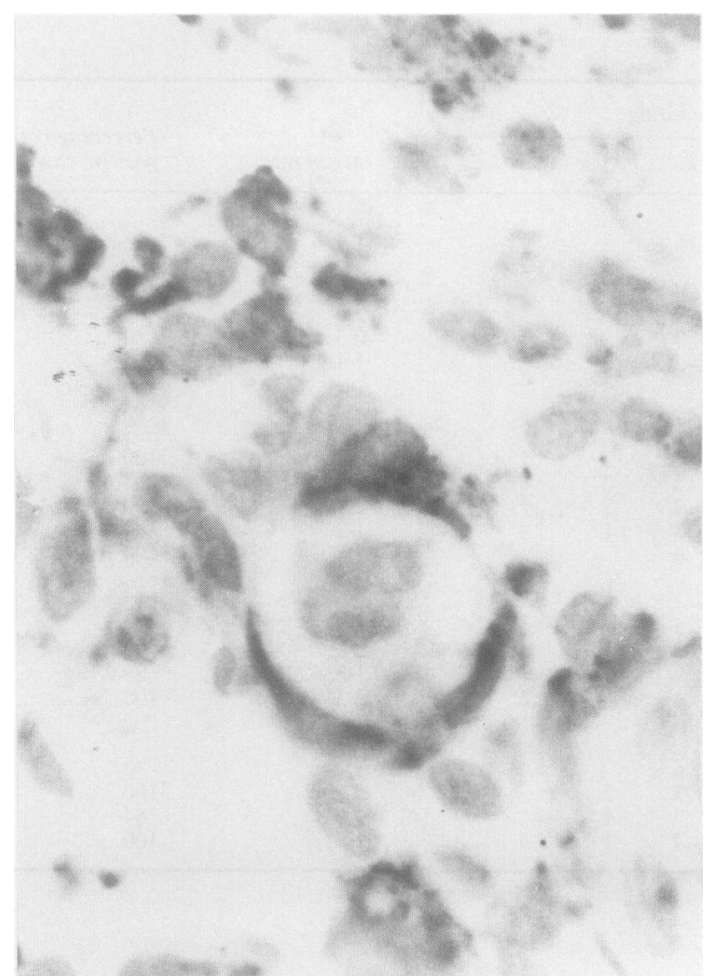

Fig 2 Atypical meningioma: whorl formation. Note tightly wrapped cells stained with RFD7 (antimacrophage monoclonal antibody).

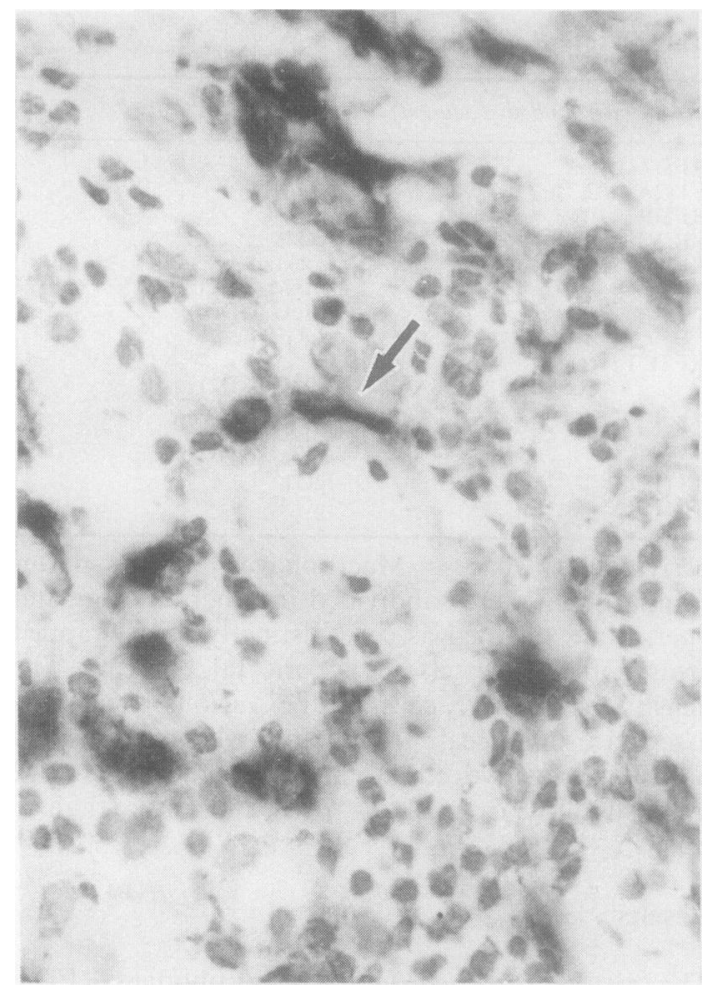

Fig 3 Atypical meningioma: perivascular macrophages and "pericytal" macrophage (arrow).( Y182A.)

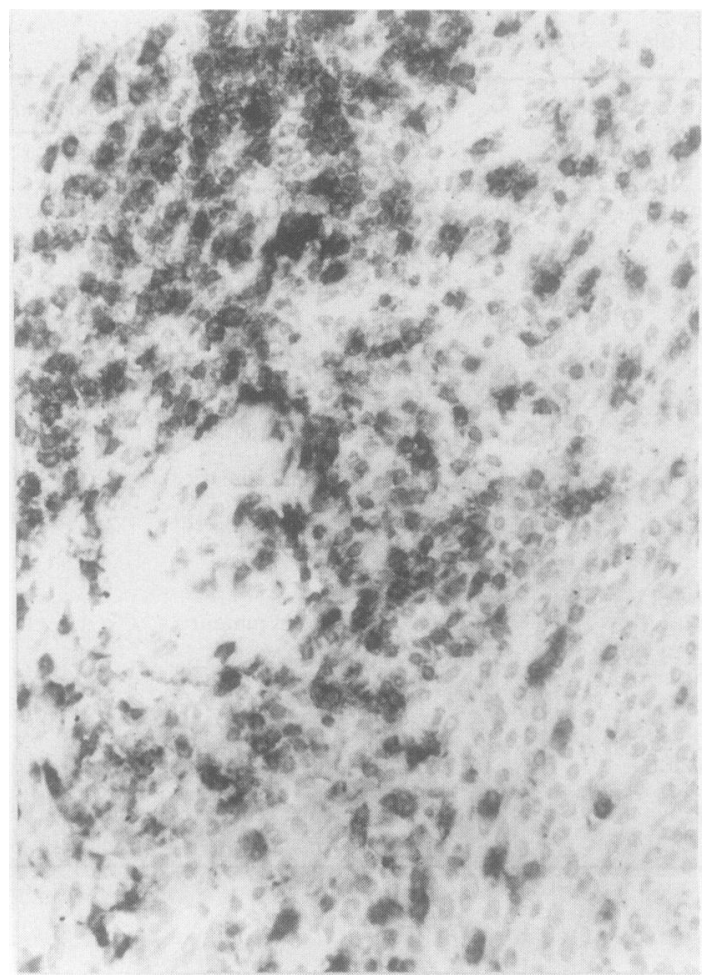

Fig 4 Atypical meningioma: note oblique blood vessel with large numbers of perivascular and parenchymal $T$ lymphocytes. (RFTCT.) 


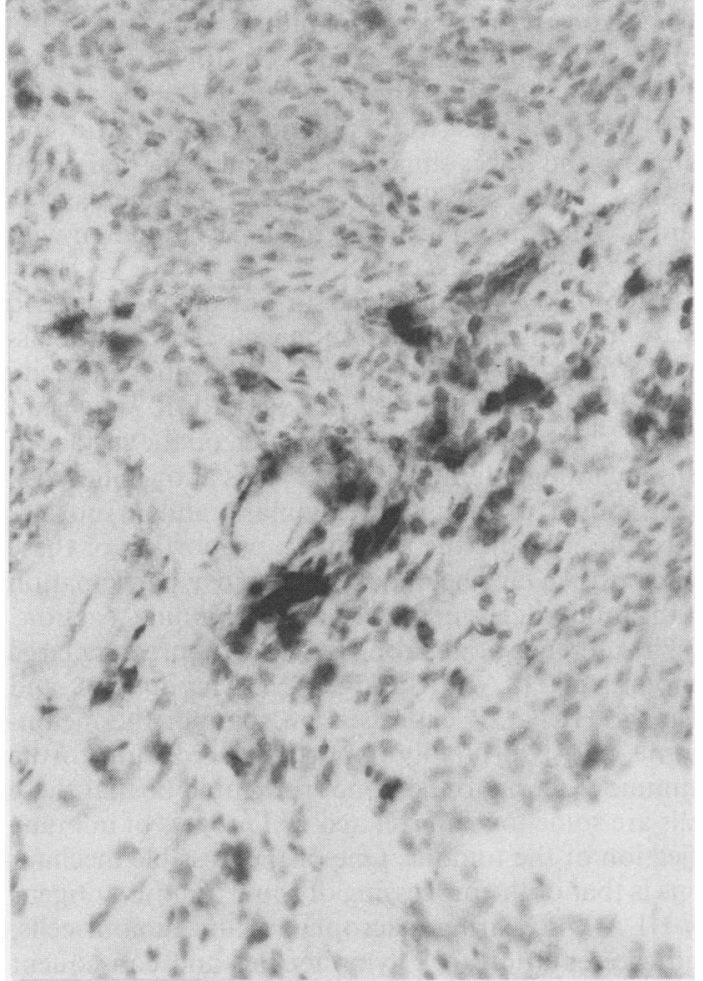

Fig 5 Benign meningioma: perivascular and parenchymal T8 lymphocytes. (T8.)

whorls it was difficult on morphological grounds alone to distinguish the cells reactive with the macrophage antibodies from the unreactive tumour cells (fig 2 ).

In perivascular spaces (fig 3) macrophages were seen in $66 \%$ with RFD7 and $84 \%$ with Y182A in benign meningiomas, the cellularity being 0.9 and 1.3 , respectively. All atypical meningiomas, on the other hand, contained macrophages, and the average cellularity with both antibodies in perivascular spaces was $2 \cdot 7$.

Macrophages in pericytal disposition (fig 3) were seen in $30 \%$ of benign meningiomas with RFD7 and in $84 \%$ with $\mathrm{Y} 182 \mathrm{~A}$, the cellularity being 0.5 and 1.2 , respectively. In atypical meningiomas RFD7 showed macrophages in $85 \%$ and $\mathrm{Y} 182 \mathrm{~A}$ in $100 \%$; the cellularity was 1.8 with both antibodies. Macrophages also showed strong positivity in all areas with the HLA DR antibody VICY1 and weaker positivity with RFDR 1 .

In benign meningiomas $\mathrm{T}$ lymphocytes, identified with the antibody cocktail RFTCT, were present in $94 \%$ of tumours within parenchyma; all the atypical meningiomas were positive. The cellularity was 1.2 in

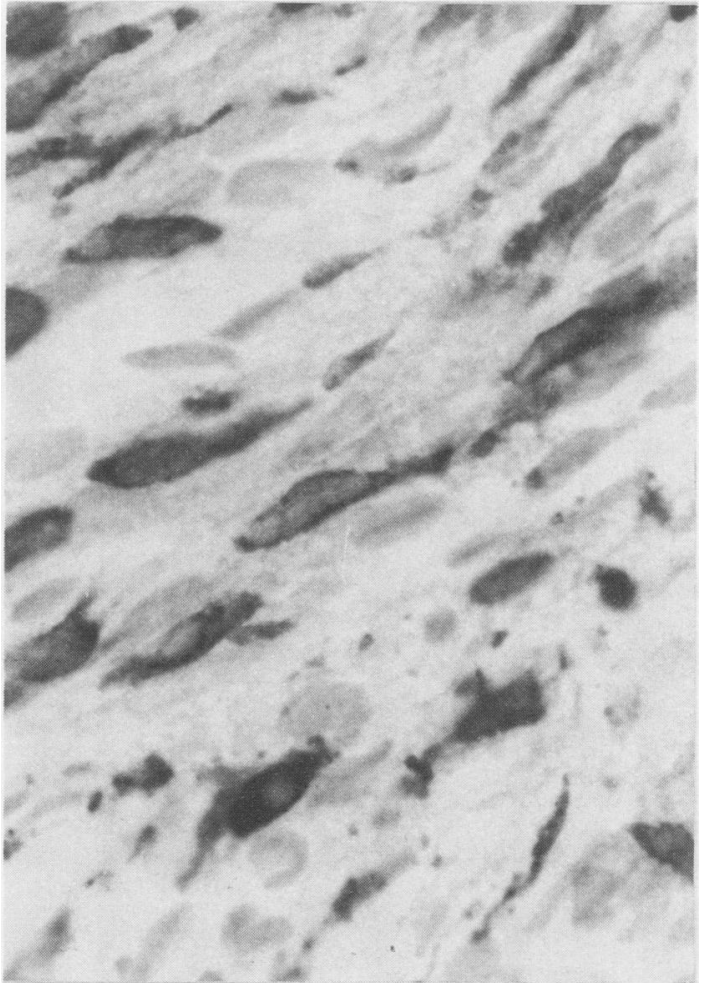

Fig 6 Benign meningioma: tumour parenchyma with spindle cells interpreted as tumour cells reactive with VICYI (antiMHC invariant chain).

benign meningiomas and 2 in atypical meningiomas. Atypical meningiomas also showed more $T$ lymphocytes in perivascular spaces (fig 4 ) than benign meningiomas (cellularity $2.3 v 1.5$ ), and in a higher percentage of cases $(100 \% v 88 \%)$.

T8 positive lymphocytes were distributed within both groups of meningiomas in a pattern similar to that observed with RFTCT within tumour and in perivascular spaces. Benign meningiomas showed positivity in $70 \%$ of cases within the tumour (average cellularity 1) and in $64 \%$ of cases in perivascular spaces (cellularity 0.9) (fig 5). By contrast, the atypical meningiomas showed T8 lymphocytes in both areas in all cases and the average cellularity was 2 and $1 \cdot 8$, respectively.

T4 lymphocytes were present in minimal numbers in one benign meningioma and in moderate numbers in one atypical meningioma. B lymphocytes were present in very small numbers in three atypical meningiomas and one benign meningioma. HLA DR antigen was detected with the antibody RFDR 1 on tumour cells in $64 \%$ of benign meningiomas and in $57 \%$ of atypical 


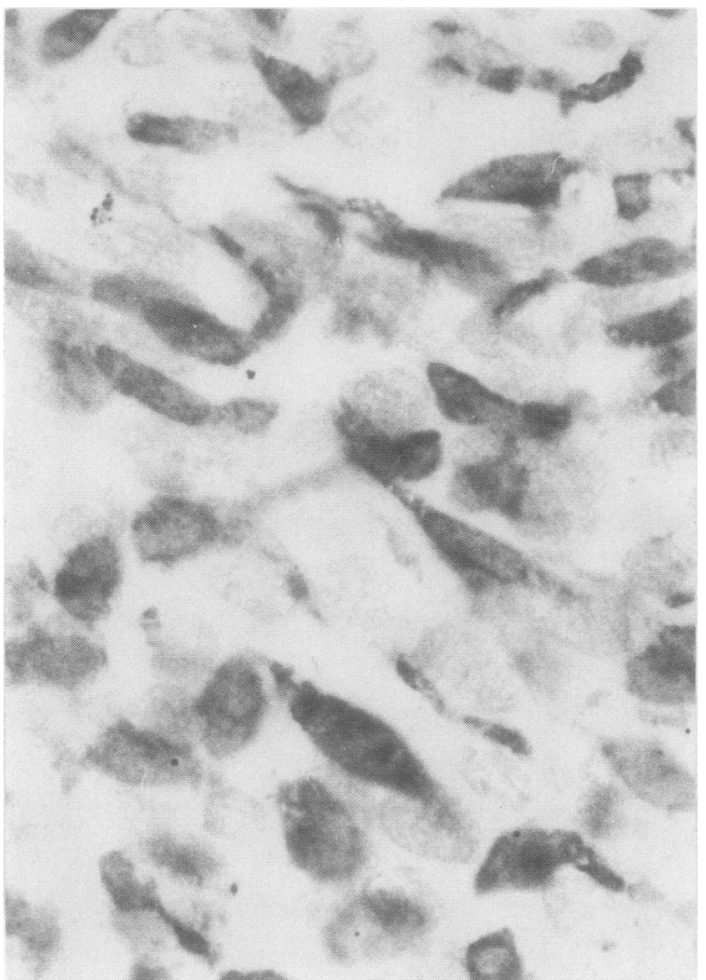

Fig 7 Atypical meningioma: tumour cells staining for $H L A$ DR as in fig 6. (VICY1.)

meningiomas. VICY1 showed cytoplasmic positivity in six of nine benign meningiomas (fig 6) and in two of seven atypical meningiomas (fig 7).

\section{Discussion}

Previous studies have shown that meningiomas have a large macrophage infiltrate, and in one report these averaged $42 \%$ (with a range between 5 and $80 \%$ ) of the total number of cells obtained from tumour cell suspensions." The clinical importance of these findings is still not clear and whether they are associated with a better prognosis in a particular tumour is not known. A possible interpretation of the higher number of macrophages infiltrating atypical meningiomas is that these reflect a stronger immune response to more aggressive tumours. This could be supported by the finding that two of our atypical meningiomas were recurrences at eight and 12 year intervals.

The absence of frank necrosis in the sections of atypical meningiomas studied suggests that they are not solely concerned with the phagocytosis of cell debris.

T lymphocytes have been shown in meningiomas in a limited series and a predominance of $\mathrm{T} 8$ in one of four benign meningiomas and one of one atypical meningioma has been shown. ${ }^{10}$

T4 lymphocytes were practically absent in our tumours and this is similar to the finding in malignant gliomas. ${ }^{19}$ We also found a four fold increase in lymphocytes in atypical meningiomas compared with benign meningiomas.

Some of the meningiomas in our study expressed HLA DR antigens within tumour cells. After cytoplasmic processing (stage recognised by the antibody VICY1 directed against the HLADR invariant chain $)^{2021}$ HLA DR antigen is located on the surface of cells including "immune" cells. ${ }^{22}$ This antigen has also been shown in malignant gliomas ${ }^{19}$ and in normal astrocytes, ${ }^{2324}$ and the fact that a proportion of these were positive may be indicative of active participation of the tumour cells in the process of immune reaction.

The presence of macrophages (also expressing large amounts of HLA DR antigen), T lymphocytes, and also the HLA DR expressed on some of the meningioma cells is probably important in relation to the immune reaction to the tumour. It could be that these cells are somehow interrelated in a process of immune rejection of the tumour. One of the possible mechanisms is that of the processing of some tumour antigens by HLA DR bearing macrophages and tumour cells, with presentation to $\mathrm{T}$ lymphocytes and consequent activation of the latter. ${ }^{25}$

As far as we know this study is the first to report that the numbers of macrophages and T and CD8 lymphocytes in meningiomas are related to atypical histological features. The widespread presence of these cells in meningiomas raises questions concerning the host's immune response and the possible relation of this to prognosis. The presence or absence of these infiltrates may help (combined with other histological features) to assess the likely aggressive behaviour of the tumour, although this still has to be supported by long term follow up studies.

We thank Dr T Moss for his advice and Dr K C Gatter, Professor J O'D McGee, Professor W Knapp and Professor G Janossy for supplying the antibodies. We thank Ms M Reading, Ms $\mathbf{H}$ Kidd, and Mr R Cross for the excellent technical assistance and Ms $P$ Deacon for the photography. This study was financed in part by a grant from the Oxfordshire District Health Authority and the A von Humboldt Foundation.

\section{References}

1 Underwood JC. Lymphoreticular infiltration in human tumours: prognostic and biological implications: a review. Br J Cancer 1974;30:538-48.

2 Bertrand I, Mannen $\mathbf{H}$. Etudes des reactions vasculaires dans les astrocytomes. Rev Neurol 1960;102:3-19. 
3 Brooks WH, Markesbery WR, Gupta GD, Roszman TL. Relationship of lymphocyte invasion and survival of brain tumour patients. Ann Neurol 1978;3:219-24.

4 Kril MP, Apuzzo MLJ. Observations in the study of T lymphocyte subsets by monoclonal antibodies and flow cytometric analysis in intracranial neoplastic disorders. Clin Neurosurg 1983;30:125-36.

5 Palma L, Di Lorenzo N, Guidetti B. Lymphocytic infiltrates in primary glioblastomas and recidivous gliomas: incidence, fate and relevance to prognosis in 228 operated cases. J Neurosurg 1978;49:854-61.

6 Ridley A, Cavanagh JB. Lymphocytic infiltration in gliomas: evidence of possible host resistance. Brain 1971;94:117-24.

7 Schiffer D, Croveri G, Pautasso C. Frequenza e significato degli infiltrati linfo-plasmacellulari nei gliomi umani. Tumori 1974;60:177-84.

8 Stavrou D, Anzil AP, Weidenbach W, Rodt H. Immunofluorescence study of lymphocytic infiltration in gliomas. Identification of T lymphocytes. J Neurol Sci 1977;33:275-82.

9 Takeuchi J, Barnard RO. Perivascular lymphocytic cuffing in astrocytomas. Acta Neuropathol 1976;35:265-71.

10 Von Hanwehr RI, Hofman FM, Taylor CR, Apuzzo MLJ. Mononuclear lymphoid populations infiltrating the micro environment of primary CNS tumours. Characterisation of cell subsets with monoclonal antibodies. $J$ Neurosurg 1984; 60:1138-47.

11 Wood GW, Morantz RA. Immunohistological evaluation of the lymphoreticular infiltrated in human CNS tumours. $\mathrm{JNCI}$ 1979;62:485-90.

12 Mahaley MS Jr, Brooks WH, Roszman T, Bigner DD, Dudka L, Richardson S. Immunobiology of primary intracranial tumours. Part 1: studies of the cellular and humoral general immune competence of brain tumour patients. $J$ Neurosurg 1977; 46:467-76

13 Brooks HW, Netsky MG, Normansell DE, Horwitz D. Depressed cell mediated immunity in patients with primary intracranial tumours. Characterization of a humoral immunosuppressive factor. J Exp Med 1972;136:1631-47.

14 Levy NL, Mahaley MS Jr, Day ED. In vitro demonstration of cell mediated immunity to human brain tumours. Cancer Res 1972:32:477-82.
15 Levy NY. Specificity of lymphocyte-mediated cytotoxicity in patients with primary intracranial tumours. J Immunol 1978;121:903-15.

16 Woosley RE, Mahaley S Jr, Mahaley JL, Miller GM, Brooks WH. Immunobiology of primary intracranial tumours. Part 3: microtoxicity assay of specific immune responses of brain tumour patients. $J$ Neurosurg 1977;47:871-85.

17 Morantz RA, Wood GW, Foster M, Clark M, Gollahon K. Macrophages in experimental and human tumours. Part 2: studies of the macrophage content of human brain tumours. $J$ Neurosurg 1979;50:305-11.

18 Alvarez F, Roda MJ, Romero MP, Morales C, Sarmiento MA, Blazquez MG. Malignant and atypical meningiomas: a reappraisal of clinical, histological and computed tomographic features. Neurosurg 1987;20:688-94.

19 Rossi ML, Hughes JT, Esiri MM, Coakham HB, Brownell DB. Immunohistological study of mononuclear cell infiltrate in malignant gliomas. Acta Neuropathol 1987;74:269-77.

20 Volc-Platzer B, Majdic O, Knapp W, et al. Evidence of HLA DR antigen biosynthesis in human keratinocytes in disease. $J$ Exp Med 1984;159:1784-9.

21 Yu DTY, Fu SM, Winchester J, Hunkel HG. Two types of Ia positive cells. Synthesis and exchange of Ia antigens. J Exp Med 1980;152:89s-98s.

22 Fontana A, Fierz W, Wekerle H. Astrocytes present myelin basic protein to encephalogenic T cell lines. Nature 1984;307:273-6.

23 Lampson LA, Hickey WF. Monoclonal antibody analysis of MHC expression in human brain biopsies: tissue ranging from histologically normal to that showing different levels of glial tumour involvement. J Immunol 1986;136:4054-62.

24 Traugott U, Scheinberg LC, Raine CS. On the presence of Ia positive endothelial cells and astrocytes in multiple sclerosis and its relevance to antigen presentation. J Neuroimmunol 1985; 8:1-14.

25 Werdelin $\mathrm{O}$, Schevach $\mathrm{M}$. Role of nominal antigen and Ia antigen in the binding of antigen-specific $\mathrm{T}$ lymphocytes to macrophages. J Immunol 1979;123:2779-83.

Requests for reprints to: Dr M Rossi, Department of Neuropathology, Radcliffe Infirmary, Oxford OX2 6HE, England. 